\title{
Duch liturgii w przestrzeni kościelnej
}

Zagadnienia związane z samą twórczością sakralną i jej wielorakimi oddziaływaniami ukazują się na całym świecie i to nie tylko na kanwie wystaw, sympozjów czy biennale. Organizowane zaś międzynarodowe imprezy związane z dewocjonaliami, sprzętem czy paramentami liturgicznymi, jak też budową obiektów sakralnych czy wyposażeniem ich wnętrz, często ubogacane są sesjami czy konferencjami naukowymi ${ }^{1}$. Wcale nie skupiają się na płaszczyźnie wyłącznie komercyjnej. Począwszy od pism specjalistycznych, poprzez periodyki teologiczne liturgiczne, architektoniczne czy artystyczne, pojawiają się zeszyty tematyczne lub poszczególne artykuły penetrujące jakże szerokie i wielowątkowe kwestie związane z przestrzenią kościelną, a raczej z całym kompleksem obiektów sakralnych.

\footnotetext{
${ }^{1}$ Wymieńmy tutaj choćby ważniejsze ogólnopolskie spotkania specjalistyczne skupione wokół LuBLINA: IX 1964 - wraz z muzealnikami i historykami sztuki, 1980 - Sesja pt. Zwiazki między wnętrzem kościelnym, sztukami plastycznymi, pieśnia i muzyka, XI 1982 - Seminarium SARP na temat obiektów sakralnych (Kazimierz Dolny), X 1984 - Konferencja naukowa Sekcji Historii Sztuki KUL o sztuce Kościołów wschodnich na ziemiach polskich (Rogóźno); wokół WARSZAWY: VI 1969 - Sympozjum pt. Posoborowe inspiracje w sztuce sakralnej (ATK), V 1977 - Sesja pt. Schronienie człowieka w Domu Bożym (Rada Prymasowska Budowy Kościołów), VI 1977 - Konferencja nt. Świątynia jako miejsce kultu i dzieło sztuki (Pax), IV 1978 - Sympozjum nt. Ochrona zabytków i nowe rozwiąania (Halin), IX 1983 - Referat na I Krajowym Zjeździe Duszpasterzy Środowisk Twórczych, VI 1984 - Seminarium nt. Wspótczesna architektura sakralna - Ośrodek parafialny (SARP); wokół KRAKOWA: XI 1981 - Sympozjum nt. Wspólnota liturgiczna w swojej świątyni (PAT Inst. Liturg.), V 1983 - Sesja Naukowa nt. Ethos sztuki (Mogilany), IX 1986 - Sesja nt. Nauka - sztuka - modlitwa (Stadniki), V 1998 - Konferencja Naukowa nt. Architektura sakralna w krajobrazie polskiej wsi (PAU, Politechnika Krakowska). Wymienićwypada jeszcze inne miasta, w których zorganizowano interesujące nas tu spotkania. CZĘSTOCHOWA: XII 1971 - Sesja Historyków Sztuki i Konserwatorów Zabytków nt. Obowiązek obrony kultury narodowej (Jasna Góra); PozNAŃ: 1982 - Sympozjum nt. współczesnej architektury sakralnej; KATOwICE: IX 1984 - Sympozjum nt. Sacrum a sztuka (Wyższe Śląskie Seminarium Duchowne); BiaŁYstok: V 2002 - już po raz czwarty zorganizowana Międzynarodowa Konferencja Naukowo-Techniczna nt. Budownictwo Sakralne i Monumentalne; KIELCE: VI 2002 - już po raz trzeci jako integralną i zasadniczą część merytoryczną i formacyjną Międzynarodowej Wystawy Budownictwa i Wyposażenia Kościołów, Sztuki Sakralnej i Dewocjonaliów SacroExpo organizuje się spotkania autorskie i konferencje naukowe, także o związkach architektury sakralnej z liturgią.
} 
Większość opracowań skupia się na szansach i zagrożeniach wynikających z interpretacji litery i ducha odnowionej liturgii, a raczej całego Soboru Watykańskiego II w kontekście twórczości sakralnej i jej różnorakich odniesień. Problem jest jeszcze bardziej złożony, gdy dotyczy implikacji odnowy liturgicznej do obiektów zabytkowych. W nowych zaś - w związku z niepełnym, a czasem całkiem błędnym pojmowaniem i realizowaniem w tychże przestrzeniach ducha Vaticanum II. Zagrożenia są przeróżne i wieloaspektowe: od kurczowego opowiadania się w różnych częściach świata za historyzmem liturgicznym i artystycznym, aż po liberalne i laksistowskie pojmowanie także tego wszystkiego, co współtworzy sacrum kościelne. Niezależnie zaś od czasu i przestrzeni - także do naszych kościołów - różnymi sposobami i drogami przenika dość często przeciętność a nawet nieład, tandeta i kicz.

Troską ludzi Kościoła, świeckich i duchownych, jest (przynajmniej powinno być) konsekwentne dążenie i dbałość o uzdrowienie różnorakich wypaczeń. Zarazem konieczne się staje, by nasze pokolenie na nowo wczytało się w treść, liczne komentarze i faktyczną realizację wraz z zawartą tamże reinterpretacją soborowych i posoborowych wymogów związanych z kościołami dawnymi i współczesnymi. Rad byłbym, gdyby w tym duchu odebrana została niniejsza moja wypowiedź. Może ona rozpocząć pewien cykl publikacji.

\section{Związki liturgii i sztuki}

Wspólnota wiernych realizuje się w sposób szczególny poprzez słowa, znaki i symbole, które są uczestnictwem w Misterium Paschalnym (KL 123). Bardzo nowoczesne formy architektoniczne kościołów, mają przede wszystkim ułatwiać spotkanie z Bogiem poprzez uciszenie zewnętrzne i wewnętrzne, w tym również przystosowanie do skupienia, rozmyślania, medytacji czy kontemplacji. Prostota nie jest pustką, ale zamierzonym działaniem przestrzennym i plastycznym, poprzez które uzyskujemy większą przejrzystość samego obiektu oraz czytelność sprawowanych tamże obrzędów. Bardzo wskazana jest tu powściągliwość, unikanie przesytu i nadmiaru. Odpowiedni efekt osiągnąć można skuteczniej właśnie poprzez proste a szlachetne materiały i formy ${ }^{2}$. Ołtarz i cała jego ikonosfera mają jednoznacznie wynikać z założeń architektonicznych. Te zaś z kolei, muszą liczyć się z wymogami liturgicznymi wnętrza ${ }^{3}$. Kościół bowiem nie jest salą koncertową czy innym świeckim obiektem użyteczności publicznej. Nie jest również rodzajem

${ }^{2}$ T. Filthaut, Kirchenbau und Liturgiereform, Mainz 1965, s. 12, wyraża potrzeby i oczekiwania współczesnej przestrzeni kościelnej.

${ }^{3}$ A. Henze, Moderne christliche Plastik, Aschaffenburg 1962 (Der Christ in der Welt, XV, 7), s. 52. 
muzeum, czyli miejscem gromadzenia drogocennych, dawnych czy współczesnych przedmiotów lub sprzętów. W przestrzeni kościelnej ma być przede wszystkim oddawana cześć i chwała Boża - ad maiorem Dei gloriam ${ }^{4}$.

Liturgia i wnętrze kościelne należą do siebie nawzajem i od siebie zależą Podkreśla się ich wewnętrzny związek. Ulegające pewnym przekształceniom wnętrze kościoła wywierało wpływ na rozwój samej liturgii. Liturgia nie została przecież ustanowiona dla ludzi jednej określonej epoki. Wraz z ludźmi, ich kulturą, mentalnością, zdolnością percepcyjną, niejako ze swej natury, ulegała więc zmianom. Następowały też przemieszania stylów i form, oraz przekształcenia przestrzeni związanej z jej sprawowaniem ${ }^{6}$. Stąd mówimy o jej charakterze rozwojowym, przystosowawczym. Treści i formy prawd, które dał Jezus Chrystus, mają być przystępne i przybliżane, także współczesnemu człowiekowi, i aż po kres czasów. Tym bardziej odnosi się to do architektury i sztuki, które mają charakter rozwojowy. Przestrzeń kościelna jest jakby wypadkową wzajemnych wpływów i powiązań ludzkiej twórczości z pogranicza liturgii i sztuki. Mówi się, że chrześcijańska budowla kościelna, aby była funkcjonalna, musi pełnić podwójną rolę: kontemplacyjną i uaktywniającą. Przestrzeń kościelna ma nade wszystko uciszać i wytwarzać odpowiedni nastrój, ale także zespalać obecnych i pobudzać ich do czynnego uczestnictwa liturgicznego. „Ort des Schweigens und der Sammlung macht”7. To właśnie liturgia ma pobudzać nie tylko natchnienie oraz inwencję twórcą, ale niejako „od wewnątrz oraz w głąb” przenikać te dzieła nie tyle literą, prawem czy rytuałem liturgicznym, ile przede wszystkim duchem i szeroko pojętą funkcją liturgiczną ${ }^{8}$.

Wnętrze kościoła musi oddziaływać poprzez moc i wymowę środków wy$\mathrm{razu}^{9}$, poprzez wartość formy i kunszt artystyczny, poprzez barwy i wykonanie plastyczne, natężenie nastroju i potęgowanie się klimatu sakralnego, i wreszcie - wytwarzanie niepowtarzalnej atmosfery modlitewnej. Według KL przestrzeń kościelna ma być przede wszystkim „godna” i „piękna” (nr 122). Nie ma to jednak być sztuczne „upiększanie” czy „dekoracyjność”.

${ }^{4}$ A. Schilling, Überlegungen zur Gesteltung des Altars, „Christliche Kunstblätter” 1 (1965), s. 13; K. RichteR, Raumgestalt und Glaubensgehalt. Der liturgische Raum prägt den Glauben, „Kunst und Kirche” 2 (1993), s. 102.

${ }^{5}$ E. Egloff, Liturgie und Kirchenbau. Principien und Anregungen, t. 1, Zürich 1964, s. 9: „zueinander in Beziehung”.

${ }^{6}$ U. MAINZER, Zur Entwicklung und Bedeutung sakraler Räume, „Kunst und Kirche” 2 (1993), s. 108 n.

${ }^{7}$ A. M. Cocagnac, Die liturgische Funktion. [w:] Kirchenbauten von Hermann Baur und Fritz Metzger, Zürich 1956, s. 69.

${ }^{8}$ I. Antoniutti, Liturgia e ispirazione artistica, „Fede e Arte” 1-2 (1958), s. 9.

${ }^{9}$ H. Muck, Kommentar zur Instruktion, „Christliche Kunstblätter” 1 (1965), s. 6. 
Groziłoby to bowiem nie tylko zatraceniem czytelności obiektu i jego pierwszoplanowej funkcji, ale byłoby zarazem przejawem kiczu. Powiązanie liturgii i sztuki oraz ich wzajemnej współzależności ukazuje także Ogólne wprowadzenie do Mszału Rzymskiego (1969) - ważny dokument, który był już kolejnym etapem percepcji odnowionej liturgii, jak również przystosowanego do niej wnętrza kościelnego w duchu posoborowym ${ }^{10}$.

Liturgiczne uporządkowanie i przyporządkowanie budowli kościelnej jednoznacznie podkreśla sens i wartość oraz przeznaczenie przestrzeni kościelnej. Żaden argument - ani formalny, ani artystyczny - nie może stanowić celu samego w sobie. Tym bardziej - dekoracyjność. Funkcja ma współtworzyć strukturę budowli i z nią harmonizowaćc ${ }^{11}$. Ważna jest nie tylko treść architektury, temat ikonografii wnętrza, struktura poszczególnych jej stref, ale także cała warstwa artystyczna i estetyczna. Jakże często konkretne dzieło zyskuje ostateczny walor właśnie dzięki formie, dzięki sposobowi przedstawienia ${ }^{12}$. Podejmowanie decyzji musi uwzględniać wiele aspektów, ustaleń, zasad czy instrukcji. Zawsze jednak musi mieć charakter bardzo konkretny i jednostkowy tego oto kościoła, budowanego w tym miejscu, w tym czasie i dla bardzo konkretnych odbiorców ${ }^{13}$.

Docenić i dowartościować trzeba nastrój całego obiektu, dominujący temat czy ideę przewodnią wnętrza, koloryt, oświetlenie. Wchodzący do kościoła powinien odczuwać zamierzoną j e d n o ść oraz integralną c a ł o ść przestrzeni sakralnej. Szczególne znaczenie ma tu gra i wymowa świateł. Mają one uwypuklać zasadniczą strukturę architektury, a także nade wszystko - hierarchię elementów wnętrza.

\section{Priorytet architektury}

Dość powszechnie się twierdzi, że architektura jest czymś pierwszym, niemal archetypicznym. Jest czymś dominującym, odczuwalnym, oczywistym. Według Adama Miłobędzkiego właśnie dlatego jest zarazem jakby „niedefiniowalna”. Z budowlą, z domem czy zespołem budynków stykamy się na co dzień i na każdym kroku. „Można żyć długo, nie słysząc muzy-

${ }^{10}$ H. NAdrowski, Przystosowalność liturgiczna wnętrza sakralnego wg „Ogólnego Wprowadzenia do Mszału Rzymskiego”, „Ateneum Kapłańskie” 5 (wrzesień-październik 1973) z. 388 t. 81 , s. 305-309.

${ }^{11}$ F. Metzger, Architektur in Dienste der Kirche, [w:] Kirchenbauten von Hermann Baur und Fritz, Zürich 1956, s. 70.

${ }^{12}$ H. Muck, Sakralbau heute, t. 1, Aschaffenburg 1961, s. 112-117 (Das Christ in der Welt, XV, 5).

${ }^{13}$ K. ChWAlibóg, O architekturze sakralnej, „Architekt” (SARP) 4 (2001) nr 16, s. 18.

${ }^{14}$ M. LEŚnIAKOwSKA, Co to jest architektura?, Warszawa 1996, s. 5. 
ki [...], nie zajrzeć do zbiorów i na wystawy malarstwa i rzeźby i ani razu nie być w teatrze, można nie czytać i nie znać poezji, ale od wpływów architektury ujść nikt nie może. Ogromna większość narodu żyje poza sferą działania innych sztuk [...]. Ale poza sferą działania architektury można żyć tylko na pustyni”. Tymi znamiennymi słowami wypowiedzianymi niemal sto lat temu przez Stanisława Pieńkowskiego rozpoczyna swą publikację współczesna autorka o istocie i zadaniach architektury ${ }^{14}$.

Kontynuując powyższy wątek należy stwierdzić, że spośród wszystkich dziedzin sztuki, właśnie architektura ma, jak słusznie zauważa Heinrich Lützeler, charakter najbardziej publiczny ${ }^{15}$ i zarazem dominujący ${ }^{16}$. Jest sztuką w najpełniejszym tego słowa znaczeniu ${ }^{17}$. Znajduje to uzasadnienie najpierw w ujęciu historycznym. Współtworzy ona całą otaczającą rzeczywistość „od zawsze” jako: mieszkanie, czyli dom zwykłych ludzi, pałac - dom władców, grobowiec - dom zmarłych czy wreszcie jako kościół i świątynia, czyli dom Boży.

Te ostatnie, to „święte domy” w odróżnieniu od pozostałych - świeckich $^{18}$. Te święte budowle, zarówno w religiach pogańskich, w judaizmie, jak i w chrześcijaństwie, mają swe odniesienie do bóstwa. W świątyniach jednak pogańskich stawiany „przybytek” jest mieszkaniem tylko dla samego Boga. W pozostałych - podkreśla się związek tych dzieł i wytworów z człowiekiem ${ }^{19}$. Najbardziej wyraziste jest to w architekturze chrześcijańskiej ${ }^{20}$. Dotyczy to zarówno koncepcji dzieła, jego kreacji, jak i percepcji oraz użytkowania. „Cała przestrzeń kościelna, jak i sztuka z nią związana była odbiciem myślenia, ducha modlitwy oraz świadomości liturgicznej danego pokolenia”21.

Budowla kościelna pełniła różne funkcje, ulegała przekształceniom oraz rozmaitym relacjom z tzw. formami „organicznymi”. Jest to (zazwyczaj) dość obszerne pomieszczenie, przykryte oraz zamknięte ${ }^{22}$. W dziejach architektury spotykamy różne założenia i kompozycje przestrzeni kościelnych: trójpolowe, dwupodziałowe, jednonawowe, owalne, elipsoidalne i zupełnie niesymetryczne ${ }^{23}$.

${ }^{15}$ H. LÜTZELER, Führer zur Kunst..., s. 6.

${ }^{16}$ H. BAur, Die christliche Kunst der Gegenwart in der Schweiz, „Das Münster” 3-4 (1959), s. 109n; por. L. Nervi, Problemi dell'architettura sacra, „Fede e Arte” 4 (1965), s. 444-451.

${ }^{17}$ H. LütZeler, Führer zur Kunst..., s. 6 : „, die Architektur ist die am meisten öffentliche Kunst".

${ }^{18}$ R. Grosche, Überlegungen zur Theologie des Kirchenbaues, „Das Münster” 9-10 (1960), s. 345; H. LÜTZELER, Führer zur Kunst..., s. 10-11.

${ }^{19}$ H. LÜTZELER, Führer zur Kunst..., s. 23.

${ }^{20}$ M. Ochsé, L'Art sacrée pour notre temps, Paris 1959, s. 16.

${ }^{21}$ H. NADROwSKI, Sztuka sakralna a teologowie, twórcy i odbiorcy, „Reklama KAI” nr 3 (jesień 2001), s. 15. Cały numer specjalny pt. Budownictwo sakralne.

${ }^{22}$ B. M. A. Ghetti, Il problema construttivo ed estetico della chiesa, „Fede e Arte” 4-5 (1958), s. 120. 
Można chyba śmiało powiedzieć, że cały problem również współczesnej sztuki sakralnej, ostatecznie sprowadza się najpierw i przede wszystkim do architektury ${ }^{24}$. Antropomorficzne, a raczej humanistyczne i personalistyczne kryteria „dookreślają” styl, formę, język także tej specyficznej architektury. Musi ona uwzględniać człowieka nie tyle historycznego, ile współczesnego. To warunkuje zrozumienie i przeżywanie jej języka i formy ${ }^{25}$.

\section{Wspólny cel, rozdzielone zadania}

Ponieważ wkraczamy tu w dziedzinę oddziaływania nie tylko przestrzennego, ale wręcz „usakralniającego”, stąd potrzeba współpracy wszystkich osób i środowisk, które twórczo mają kształtować obiekt sakralny i jego otoczenie. Integralne i kompetentne działanie może dać właściwe efekty. Wśród osób nadających ton i końcowy rezonans, niejako na pierwszy plan wysuwają się: t e olog i a r ty s ta. Tym pierwszym jest zazwyczaj proboszcz - inwestor danego kościoła; tym drugim - najpierw i przede wszystkim architekt. Punkt widzenia każdego z nich o tym samym obiekcie jest ex officio zazwyczaj nieco (a czasem nawet bardzo!) odmienny. Pierwszy akcentuje wewnętrzną spójność dzieła przede wszystkim dzięki prymatowi teologiczno-biblijnemu oraz zadbaniu o modlitewną i liturgiczną jego funkcjonalność. Drugi - z zasady zwraca uwagę na b u d o w lę jako taką. W polu jego zainteresowania będzie więc logiczna struktura całości, integralna forma, wzajemne oddziaływanie na siebie elementów konstrukcyjnych, zastosowanie sprawdzonych odkryć technicznych, uwzględnienie możliwości materiałowej, a jednocześnie pobudzenie wyobraźni ku realnym, ale i odważnym rozwiązaniom, które pozwolą mu uwolnić się od rutyny.

Ostatecznie obydwaj zmierzają do wydobycia indywidualnych i społecznych funkcji architektury sakralnej, choć z różnych punktów widzenia. Rzecz w tym, by owe dążenia zespolić. Konsekwencją ich wzajemnego kontaktu i dialogu powinno być stworzenie kościoła naprawdę nowoczesnego i zarazem w pełni zaspokajającego potrzeby społeczności wiernych, potrzeby konkretnej wspólnoty ${ }^{26}$. Można powiedzieć, że z różnym nasileniem pojawiają się zarówno w liturgii, jak i sztuce z nią związanej, dwie skrajności: $n$ i e b e z pi eczénstwo zbytniego wyizolowanego sacrum

${ }^{23}$ U. MAInZER, Zur Entwicklung..., s. 108.

${ }^{24}$ F. DeBuyst, Le problème actuel de l'art sacré, „L'art d'glise” 105 (1958), s. 139.

${ }^{25}$ E. Egloff, Liturgie und Kirchenbau...; por. G. Rombold, Liturgie und Kirchenbau, „Christliche Kunstblätter” 1 (1965), s. 20-21.

${ }^{26}$ H. Muck, Sakralbau heute..., s. 11-13. 
z c o d z i e n n e g o ż y c i a, jak również takie eksperymentowanie, które jest faktyczną desakralizacją a nawet profanacją świętych miejsc i przedmiotów. Bolał nad tym papież w przemówieniu do Posoborowej Rady Liturgicznej ${ }^{27}$.

Pozytywnym przejawem współczesnej twórczości architektonicznej jest jej charakter dynamiczny ${ }^{28}$. Także sfera sacrum powinna być wyrażana poprawnym językiem architektury i plastyki swojego czasu ${ }^{29}$. Sięgamy do praźródła językowego i wspólnego kodu informacyjnego. Język twórczości i warsztat jest ostatecznie ten sam, co w formach świeckich. Posługiwanie się tym językiem jest szansą, choć według innych stwarza całkiem realne $\mathrm{z}$ a g r o ż e $\mathrm{n}$ i a a nawet $\mathrm{k} \mathrm{r} \mathrm{y} \mathrm{z} \mathrm{y} \mathrm{s}{ }^{30}$. Pamiętajmy, że także niektórzy ludzie współczesnego Kościoła nie uwolnili się od zachowawczych tendencji oraz lęków wobec wszelkiego postępu i nowości.

Poprzez co ma być osiąnnięte owe usakralnienie obiektu kościelnego? Z jednej strony przez autentyczne, odwewnętrzne działanie artysty, a z drugiej strony przez funkcjonalność danego obiektu. Najpierw więc, architekt musi być oryginalny ${ }^{31}$. Musi tworzyć to, co przeżył, to co wypływa z jego osobowości, z jego w n ę t r z a . „Tyle jest stylów architektonicznych, ile stylów osobowościowych", jak słusznie zauważa Frank Lloyd Wright ${ }^{32}$. Ostatecznie to nie jedynie czas, w którym żyje twórca ani związek z jakimś stylem czy kierunkiem artystycznym decydują o wartości i oryginalności dzieła sakralnego, ale właśnie osobowość twórcy i jego duchowe oblicze. Stan rzeczy to właściwie „stan ducha" społeczeństwa danego czasu ${ }^{33}$, które wydaje przecież zarówno kapłanów - inwestorów, jak i twórców - architektów i plastyków.

\section{Międzynarodowy czy własny}

Z różnym nasileniem pojawia się chęć nawrotu do tzw. „stylu międzynarodowego". Prekursorami takiego pojmowania najnowszej architektury

${ }^{27}$ G. M. LukKen, Czy liturgia ma przyszłość?, „Ruch Biblijny i Liturgiczny” 2-3 (1970), s. 117. Zob. też „Notitiae” 13 (1968), 338.

${ }^{28}$ G. RомвоLD, Gegensätzliche Tendenzen im heutigen Kirchenbau, „Christliche Kunstblätter" 2 (1966), s. 26n.

${ }^{29}$ H. NADROwSKI, Twórca i odbiorca sztuki sakralnej naszych czasów, „Studia Theologica Varsaviensia” 1 (1987), s. 76-81.

${ }^{30}$ M. C. Laurent, Valeur chrétienne de l'art, Paris 1959, s. 77.

${ }^{31}$ Znamienne są słowa Waltera Gropiusa, które cytuje jako motto swego artykułu G. Rombold, Gegensätzliche Tendenzen..., s. 25: „Ich möchte kein fertiges Dogma lehren, sondern eine vorurtelslose, orginale und elistische Haltung und Problemem unserer Zeit gegenüber".

${ }^{32}$ Zob. powt. za G. Rombold, Gegensätzliche Tendenzen..., s. 25: „So viele Architekturstile wie Persönlichkeitsstile".

${ }^{33}$ H. NADrowSKI, «Sztuka Sakralna» - czyli jakie pismo?, „Sztuka Sakralna” nr 1 (2002), s. 5. 
kościelnej są: Rudolf Schwarz (już w 1930 r.), Frank Lloyd Wright, Le Corbusier $^{34}$. Stosowana też bywa nazwa „styl uniwersalny”35. Kościół - wg nich - musi być nowoczesny, zrozumiały dla wszystkich narodowości i grup społecznych. Nowo powstające kościoły muszą mieć celowe rozwiązania geometryczne (a raczej stereometryczne) i plastyczne podkreślające przestrzenność, jasność, a przede wszystkim funkcjonalność. Szczególnie podkreśla się związek architektury z plastyką i mówi się o nowej formie tzw. „architekturo-plastyce”, której świetnym przykładem jest kaplica w Ronchamp (1951-1955) Le Corbusiera. Już obecnie trudno by podtrzymać słuszność tezy o bardziej bezpośrednim związku z kultem raczej samej plastyki niż architektury kościoła ${ }^{36}$. Coraz powszechniej dąży się raczej do łącznego ujmowania plastyki i architektury ${ }^{37}$.

Jednocześnie pojawiają się racje broniące priorytetu najpierw i przede wszystkim charakteru „rodzimego” budowanych kościołów. Nowe budowle sakralne mają być ściśle powiązane z kulturą i folklorem narodu, ze sztuką regionu. Odnosi się to zarówno do kościołów powstających w Europie, jak i w innych częściach świata. Wprost rewelacyjne (na kilka lat po zakończeniu drugiej wojny światowej) było głośne i dobitne propagowanie tej tendencji przez kard. Constantiniego ${ }^{38}$. Zauważmy, że również w Polsce oprócz kościołów utrzymanych w konwencji uniwersalnej, międzynarodowej, pojawia się wyraźna dążność do podkreślania cech danego środowiska czy regionu. Szczególnym tego przejawem jest nawiązywanie do artystycznych konwencji stylu ludowego lub jego reminiscencji, głównie na Podhalu, Beskidzie czy Śląsku.

Wiadomo, że konkretne środowisko, kultura i tradycja stanowią ścisłe implikacje architektury jako takiej. Pamiętając o tym, trzeba zadbać o: z jednej strony o d r ę b n y charakter architektury sakralnej, z drugiej zaś - ścisły związek i konieczność i n t e g r a c j i z architekturą świecką ${ }^{39}$. Już same mury, sama oprawa architektoniczna muszą być przepojone sakralnością. Cały problem - jak to uczynić? Sprawa jest dość złożona. Odmienny jest bowiem charakter architektury kościelnej, a inny - budowli świeckich. Kościół jest przede wszystkim zarazem Domem Bożym, jak i obiektem

${ }^{34}$ G. Rombold, Gegensätzliche Tendenzen..., s. 25.

${ }^{35}$ J. WAGNER: L'art liturgique et la pastorale, „La Maison Dieu” 47-48 (1956), s. 105-126, 120.

${ }^{36}$ F. Debuyst, Le problème actuel..., s. 139.

${ }^{37}$ P. R. Régamey, Art sacrée au XXe siècle?, Paris 1952, s. 26.

${ }^{38}$ Por. C. Constantini, L'art chrétienne dans les missions, Bruges 1949. Wspomnijmy też o ferowanej przed wojną konieczności stworzenia - także w budownictwie kościelnym - odrębnego „stylu polskiego” - por. L. GościcKI, Budowa świątyni. Wskazówki praktyczne przy wznoszeniu i odbudowie kościołów oraz zdobieniu ich wnętrza, Płock 1947², s. 13-16.

${ }^{39}$ H. LÜTZELER, Führer zur Kunst..., s. 10-11. 
liturgicznym ${ }^{40}$. „Architektura kościelna nie jest jedynie, jak to się dzieje, gdy chodzi o zwykły dom, spotkaniem człowieka z przyrodą stworzoną"41. Budowla kościelna ma być włączona zarówno w przyrodę, jak w i otoczenie budowli miejskich, usakralniając je.

\section{Bliżej Boga i z myślą o człowieku}

Mówi się, że to wyjątkowe miejsce, a raczej przestrzeń uroczyście poświęcona, a zarazem uświęcona poprzez modlitwę i liturgię, powinna nie tylko immanentnie czy ontycznie, ale także formalnie i artystycznie wyrażać bliskość, otwartość i gościnę i wobec Boga, i wobec człowieka. Powinno to być czytelne i niemal intuicyjnie odczuwane - najpierw i przede wszystkim - podczas ustawicznie ponawianej tamże Najświętszej Ofiary Jezusa Chrystusa. Jednakże również bezpośrednio przed sprawowaną liturgią i po jej zakończeniu, należy zadbać o zachowanie owego specyficznego klimatu sakralnej intymności, modlitewnej zadumy czy ewangelicznej refleksji. Cała przestrzeń kościelna powinna przybliżać Boga. Wchodzący w progi kościoła - także ludzie niewierzący - powinni odczuć „,powiew boskości”, zdrową doktrynę Kościoła oraz - liturgicznie funkcjonalny charakter tej budowli. Ma być jednoznacznie czytelne, że znajdujemy się w miejscu zgromadzenia, ale zgromadzenia religijnego, sakralnego. On nie może być traktowany i odbierany tak samo, jak jeden z wielu świeckich obiektów, a jego wnętrze nie powinno być kojarzone z salą widowiskową ${ }^{42}$. Człowiek nie powinien w kościele odczuwać atmosfery kina ${ }^{43}$, sali koncertowej, sali zebrań, teatru, hali sportowej czy dworca kolejowego ${ }^{44}$. Twórca sakralny nie może stosować wzorów budowli świeckich ${ }^{45}$. Paradoksem jest, że niejeden współczesny kościół (np. z XX wieku), mimo zazwyczaj dostawianej wieży i pieczołowitego nawiązania do planów historycznych np. z trzema nawami, jednakże bez transeptu „w połączeniu «z prostotą i czystością formy» daje w wyniku budynek przypominający kino lub fabrykę". Przełomem stała się kaplica Ronchamp, która uwidacznia dwie słuszne zasady: 1) odejście od rozwiązań historycznych; 2) odrębność domu Boga od budynków świeckich. Le Corbusier we wnętrzu wspomnianego kościoła pielgrzymkowego wy-

${ }^{40}$ H. LAAn, Principes élémentaires d'architecture religieuse, „L'art d'eglise” 4 (1954), s. 302.

${ }^{41}$ F. DeBUyst, Le problème actuel..., s. 139.

${ }^{42}$ A.-M. Roguet, Liturgique pastorale, [w:] A. G. MARTIMOrt, L'Eglise en prière. Introduction à la liturgie, Paris-Tournai 1961, s. 18.

${ }^{43}$ L. M. Blanco, L'architettura al servizio della comunitá cristiana, „Fede e Arte” 2 (1966), s. 176; A. M. Roguet, Liturgique pastorale...., s. 20.

${ }^{44}$ A. M. Roguet, Liturgique pastorale ...; por. H. Muck, Sakralbau heute..., s. 100nn.

${ }^{45}$ K. B. FrAnK, Kernfragen kirchlicher..., s. 91. 
tworzył atmosferę tajemniczości a raczej misterium, a zarazem intymności ${ }^{46}$. Gdy chodzi o formę, to powiązał ze sobą poszczególne elementy niby hiperbolicznej bryły wspomnianego kościoła, a zarazem świetnie go związał z topografią terenu, „wpisał” w otaczający krajobraz. Był to początek nowego myślenia i działania przestrzennego ${ }^{47}$.

Zadaniem twórcy architektury sakralnej jest także umiejętne jakby scalenie tego, co dały mu studia przygotowujące do zawodu z tym, co jest wymogiem nauki Kościoła, jak i odpowiedzią na zapotrzebowanie wiernych. To przestrzeń kościelna: estetyczna i harmonijna, ale zarazem konsekwentna i twórcza ma przybliżać samego Boga. Taka integralna przestrzeń ma stanowić forum dla człowieka, który tam właśnie dokonuje osobliwych i wielorakich relacji ze Świętym świętych, czyli z samym Bogiem.

Trzeba z kolei podkreślić charakter $\mathrm{r}$ o z w o j o w y zarówno liturgii, jak i budownictwa kościelnego. Zawsze starano się pamiętać, że każdy kościół to dom Boży, ale jednocześnie dom d l a c zło w i e k a ${ }^{48}$. Zrozumiałe więc jest, że budowle kościelne, jeśli mają być funkcjonalne, muszą ulegać modyfikacji i przystosowaniu, w zależności od ewentualnych zmian funkcji czy systemów konstrukcyjnych. Faktycznym jednak zagrożeniem, i ostatecznie nieporozumieniem byłoby takie działanie architektoniczne, którego efektem byłoby kształtowanie przestrzeni kościelnej nawet poprzez bardzo nowoczesne formy, struktury, techniki czy technologie, które jednak lekceważyłyby, czy nawet odrzucałyby „warunki użyteczności”, w tym wypadku - liturgicznej i modlitewnej. Tak np. należy potraktować skrajne realizacje suprematyzmu czy konstruktywizmu ${ }^{49}$.

Do budowli sakralnej można, a nawet należy wprzęgnąć nowe, a nawet najnowsze sprawdzone materiały budowlane (stal, beton, szkło) oraz ich rozmaite powiązania ${ }^{50}$, ale także wiodące osiągnięcia całej myśli technicznej. To wszystko ma się dokonywać „z myślą o człowieku” i to - dzisiejszym. Twórca - architekt ma nie tyle negować świat i otaczającą rzeczywistość. Ma raczej ją uszlachetnić, wewnętrznie ożywić, nadawać nowy, głębszy wymiar. Poprzez swoje działanie ma ją integrować, a nawet uświęcaćs1.

${ }^{46}$ J. GyMPEL, Geschichte der Architektur von Antike bis heute, Köln 1996, s. 103.

${ }^{47}$ H. Muck, Sakralbau heute..., s. 92-94.

${ }^{48}$ Por. H. Merkle, Gedanken zum Kirchenbau, „Christliche Kunstblätter” 1 (1966), s. 15.

${ }^{49}$ J. BAllenstedt, Architektura. Historia i teoria, Warszawa-Poznań 2000, s. 445-449.

${ }^{50}$ G. Rombold, Gegensätzliche Tendenzen..., s. 25-28.

${ }^{51}$ K. B. Frank, Kernfragen kirchlicher..., s. 92; J. St. PASIERB, Rewolucja w architekturze (najnowsza architektura kościelna w Szwajcarii), „Sodalis” 4 (1962) nr 402, s. 114: „Przykład Ronchamp wyzwolił duże dozy pomysłowości w projektowaniu budowli sakralnych. Nowe materiały budowlane pozwalają nie liczyć się z wieloma dawniej nieprzezwyciężalnymi trudnościami technicznymi. Płaszczyzny gną się i falują, lekkie i silne tworzywa są w stanie 
Owe dzieła muszą współtworzyć misterium, a raczej mu towarzyszyć i z nim współbrzmieć podczas sprawowania liturgii czy osobistej modlitwy. Działanie artysty nie jest ani dodatkiem, ani jakimś ozdobnikiem, ale przede wszystkim specyficzną m o w ą, która posługuje się własnymi środkami wyrazu, a zarazem jest przejawem jego inwencji twórczej. To powoduje rezonans, inspiruje do wymiany myśli, pobudza do inicjatywy. To zapewni właściwy rozwój, żywotność i chłonność tego, co nowe - nie ulegając jednak „modzie” ${ }^{2}$. Działanie to nie jest na ogół gwałtowne, lecz raczej powolne, stopniowe ${ }^{53}$.

\section{Znamię eklezjalne}

Cennym wkładem w propagowaniu opinii zbliżonych do oficjalnej interpretacji wspomnianych kwestii przez Stolicę Apostolską są publikacje duchownych i świeckich w piśmie „Fede e Arte”, a czasami także „Notitiae”. Wspomnijmy choćby wypowiedź, którą stamtąd przekazał na cały świat znany architekt Luigi Nervi. Akcentuje on cztery niezbędne cechy współczesnej przestrzeni kościelnej:

1. jednolitość treściowo-formalna a zarazem duchowo-fizyczna;

2. prostota i oszczędność środków wyrazu;

3. funkcjonalność, głównie liturgiczna, tak dla celebransa, jak i dla wiernych;

4. atmosfera modlitewna ${ }^{54}$.

Ujmując zagadnienie od strony teologicznej, duszpasterskiej i socjologicznej, trzeba podkreślić, że kościół jest miejscem skupiającym zgromadzenie wiernych ${ }^{55}$ wokół ołtarza, na którym dokonuje się Ofiara Zbawienia Chrystusa Pana. Właśnie w kontekście ołtarza mamy przystęp do Boga, gdzie poprzez osobę Chrystusa stary człowiek przemienia się w nowego człowieka, zaś cały świat w Nim odradza się w nowy kosmos ${ }^{56}$. In signo obecny jest w czasie liturgii cały Chrystus. Ekklesia jest w znacze-

«powiedzieć wszystko, co pomyśli głowa» nowym językiem, pełnym poetyckiego polotu”; E. Gisel, Über Kirchenbau, „Werk” 12 (1961), s. 406; por. E. StefanN, Katholische Kirche aus Abbruchsteinen in der Nachbarschaft der Kölner Universität, „Baumeister” 8 (1963), s. 817820; por. H. Muck, Sakralbau heute..., s. 7n.

${ }_{52}$ P. R. Regamey, Art sacrée ..., s. 105-106; por. K. Ledergerber, Kunst und Religion in der Verwandlung, Köln 1961, s. 31.

${ }^{53}$ R. K. Seasoltz, The House of God. Sacred Art and Church Architecture, New York 1963, s. 44n.

${ }^{54}$ L. Nervi, Problemi dell'architettura ..., s. 445-450.

${ }_{55}$ A.-M. Roguet, Construire et aménager les églises, Paris 1965. L'esprit liturgique 25, s. 19.

${ }^{56}$ O. Moosbrugger, Die katholische Kirche als Bauherrin, „Bauen und Wohnen” 11 (1958), s. 361. 
niu analogicznym spotkaniem się Mistycznego Ciała Chrystusa w jednej akcji liturgicznej: Głowy i członków tego Ciała, czyli obecnością in signo cał ego Chrystusa ${ }^{57}$. Właśnie w czasie wspólnego sprawowania Ofiary eucharystycznej zostajemy „wbudowani” w Ciało Chrystusa. To ołtarz i przestrzeń go otaczająca, gdzie jest obecny Pan Jezus, jest miejscem oblubieńczej miłości z Chrystusem i wreszcie - miejscem spotkania żywego Kościoła tzn. braci i sióstr w Chrystusie ${ }^{58}$. Budowla sakralna ma także wyraźnie, ale i symbolicznie, wyrażać ideę nowego ludu Bożego, który urzeczywistnia nowe królestwo o znamionach powszechności, świętości, apostolskości. Ma obejmować wszystkie osoby i rzeczy w niebie i na ziemi. Zarazem ma wyrażać pneumatyczny i eklezjalny charakter Ciała Chrystusa „właśnie w Kościele i przez Kościół [...], który ukonstytuowany został przez wylanie Ducha Świętego w dniu Zielonych Świąt" ${ }^{59}$. Jest to więc też miejsce jedności, braterstwa i solidarności z wszystkimi ludźmi, z całym światem. Zgromadzenie to aktualizuje się w jednym obiekcie kultycznym, co uwypukla właśnie ów architektoniczny aspekt tego zagadnienia ${ }^{60}$. Ową „uhierarchizowaną jedność ludu Bożego ma wyrażać, symbolizować i uskuteczniać cały rozkład budowli, jej artystyczny wystrój, wewnętrzne wyposażenie i rozkład poszczególnych elementów kultowych wewnątrz świątyni”61.

Nieustanna więź wiernych z Chrystusem - Głową w modlitwie oraz szczególne urzeczywistnianie mocy i życia Ducha poprzez Słowo i sakramenty, podtrzymywane są właśnie w przestrzeni kościelnej, wraz z jej liturgicznym charakterem. To tu szczególnej aktualności i wyrazistości nabierają słowa św. Pawła: „Z Niego całe Ciało - zespolone i podtrzymywane w całości przez wszelką więź zaopatrującą w moc na miarę każdego z członków - przyczynia sobie wzrostu dla budowania siebie w miłości” (Ef 4, 16). Czyż nie jest to jeden z piękniejszych tekstów, który budowlę materialnego kościoła, czyli domu Boga i ludzi tam się gromadzących, przekształca w budowlę duchową i wieczną, która konsekwentnie z dnia na dzień budowana jest przede wszystkim poprzez konkretną miłość?

Cała przestrzeń kościelna - zewnętrzna i wewnętrzna ma: kształtować wspólnotę, ułatwiać przekazywanie prawd wiary, stwarzać atmosferę dialogu z Bogiem, tak poszczególnego odbiorcy, jak w osobliwy sposób - danej wspólnoty liturgicznej. Poprzez „czyn Kościoła” kształtuje się nowy lud

${ }^{57}$ M. Palacios, L'altare e i suoi servizi, „Fede e Arte” 2 (1965), s. 182.

${ }^{58}$ O. Moosbrugger, Die katholische Kirche..., s. 361.

${ }^{59}$ C. Dawson, Formowanie się chrześcijaństwa, Warszawa 1969, s. 81.

${ }^{60}$ H. LÜTZELER, Führer zur Kunst..., s. 48.

${ }^{61}$ J. KRASIŃSKI, Społeczny charakter Mszy św. według „Institutio Generalis Missalis Romani”, „Ruch Biblijny i Liturgiczny” 2-3 (1970), s. 104. 
Boży. Kościół jest budynkiem szczególnej służby oraz specjalnego czynu ${ }^{62}$. Ów charakter wspólnoty (communio) powinien być uzewnętrzniony, także od strony optycznej i akustycznej. Szczególnie wyrazistym akcentem przestrzeni liturgicznej po Vaticanum II - także symbolicznej i rzeczywistej - jest niemal powszechna praktyka stawiania ołtarza odwróconego w stronę wiernych (versus populum) oraz sprawowanie koncelebry ${ }^{63}$.

Warto zauważyć analogię budowli kościelnej z owym żywym Kościołem, czyli Mistycznym Ciałem Chrystusa. Każdy chrześcijanin nosi w sobie obraz Kościoła oraz potrzebę ustawicznego budowania go. Choć klasyczny tekst św. Pawła: „Nie jesteście już obcymi i przychodniami...” (Ef 2, 19-22) ma różne komentarze i wyjaśnienia, to niejako pierwszorzędne znaczenie dotyczy powyższego kontekstu. Głębokie teologiczne i biblijne uzasadnienie tego problemu wyraził podczas swego kazania dnia 26 kwietnia 1959 roku kardynał G. B. Montini - późniejszy papież Paweł VI ${ }^{64}$. Poprzez czyny i słowa liturgii oraz współudział w kapłaństwie hierarchicznym, chrześcijanin staje się uczestnikiem ludu kapłańskiego, będąc złączonym zarówno z pozostałymi jego „członkami”, jak i przede wszystkim z - Głową. Odkrywamy tu także ów szerszy krąg chrystocentryzmu. W Chrystusie złączone jest człowieczeństwo i cały świat. W Nim odrodził się cały wszechświat. Budowla kościelna poprzez orędzie zbawienia otwiera całemu kosmosowi przestrzeń pokoju i nowego stworzenia ${ }^{65}$. Jest ona znakiem, jak i symbolem obecności w świecie. Parafrazując słowa André Alsteensa, możemy powiedzieć, że tak jak liturgia wchodzi w naszą codzienność, podobnie ma być z budynkiem, w którym następuje owo przedziwne spotkanie ze światem. Zrozumienie i odczytanie pełnego znaczenia owego sacrum kościelnego dokonuje się dopiero w świetle konstytucji soborowej Lumen gentium oraz konstytucji ukazującej całokształt stosunków Kościół-świat, czyli Gaudium et spes ${ }^{66}$. Ustawiczne pogłębianie budowania Kościoła dokonuje się szczególnie poprzez Eucharystię i głoszenie Słowa - właśnie w kościele jako budowli ${ }^{67}$.

Włączenie się w posługę Kościołowi nie ma oznaczać skrępowania artystów, lecz ma wręcz pobudzić twórczą inwencję. Postawa zaangażowana i twórcza musi jednakże mieć ciągle charakter służebny. Tu twórca ma chłonąć niejako ducha eklezjalnego i liturgicznego zarazem, jednemu

${ }^{62}$ F. Metzger, Architektur in Dienste..., s. 19-20.

${ }^{63}$ H. NAdrowsKi, Kościoły naszych czasów. Dziedzictwo i perspektywy, Kraków 2000, s. $190-192$.

${ }^{64}$ G. B. Montini, Il segreto della Cattedrale, „Fede e Arte“ 3 (1959), s. 242-247.

${ }^{65}$ O. Moosbrugger, Die katholische Kirche..., s. 361.

${ }^{66}$ A. Alsteens, Liturgia i teologia a wyczucie teraźniejszości, „Ruch Biblijny i Liturgiczny” 4-5 (1969), s. 227.

${ }^{67}$ J. Betz, Die Eucharistie, [w:] H. Fries (Hrsg.), Wort und Sakrament, Münster 1966. 
i drugiemu nadając jednocześnie znamię duchowości, a nawet kontemplacji. Wszelkie kanony i przepisy o tyle mają sens, o ile są pomocą do urzeczywistnienia funkcji społecznej budowli kościelnej, przy jednoczesnym umożliwieniu rozwinięcia inicjatywy twórczej ${ }^{68}$. Kościół zawsze zostawiał swobodę w wyborze środków, w poszukiwaniach twórczych. Absolutnie nie można zgodzić się z poglądem, jakoby nie odpowiadały one duchowi Kościoła i liturgii i nie mogły być nazwane sakralnymi ${ }^{69}$. Magisterium Kościoła i wskazania Soboru Watykańskiego II wcale nie powinny być odbierane jako krępowanie inwencji projektanta czy artysty. Wręcz przeciwnie, wytyczając cel i podstawy teologiczne, liturgiczne i pastoralne, nie ingeruje w sprawy warsztatu, czy zastosowania takich czy innych środków, ani tym bardziej w sposób wykonania. To jest nie tyle domena fachowców, ale to ich niepozbywalne zadanie.

Trzeba zarazem zauważyć niebezpieczeństwo swoistego skostnienia po obydwu stronach. Wiadomo, że potrzebna jest znajomość historii, także historii teologii i liturgii, historii architektury i budownictwa. Trzeba korzystać z wiedzy, refleksji i doświadczenia poprzedników w różnych dziedzinach. Nie można jednak ani z wiary czy teologii, ani z liturgii uczynić szacownego zabytku, który jest nietykalnym, ale już niewspółczesnym przejawem życia Kościoła. Potrzebna jest żywa wiara ożywiana liturgią naszych dni i wpisana oraz realizowana w przestrzeniach na wskroś współczesnych, a nawet nowatorskich. To jest zadanie i obowiązek zarówno wobec naszych poprzedników na drodze wiary, jak i naszych następców. To dla człowieka współczesnego i dzięki jego zaangażowanej wierze stawiane są kościoły i urządzane ich przestrzenie. I właśnie twórcy różnego rodzaju, w tym wypadku architekci, mają temu zadaniu sprostać. Mają bronić się przed tzw. gotowymi rozwiązaniami, mają uwolnić się od samozadowolenia i zachwytu stanem zastanym czy przeszłością, choćby najbardziej udaną, ale przecież mało twórczą albo wręcz zapożyczoną czy porwaną z historii niemal mechanicznie i bezwiednie. W różnych dziedzinach prawdziwe jest poniższe stwierdzenie jednego z architektów, ale chyba szczególnie właśnie w dziedzinie działania architektonicznego, projektanckiego. Otóż przeszłość trzeba znać, umiejętnie ją odkrywać i nawet wyciągać z niej wnioski. Jednakże, „kiedy nad nią panujemy, to wtedy i tylko wtedy wznosimy się ponad nasze ograniczone możliwości i możemy poznać wolność myślenia, wolność wyboru"70. Odnosi się to też, a raczej w szczególny sposób - do architektury kościelnej.

Wspomniana przestrzeń ma pomagać w modlitwie oraz w liturgii. To właśnie służebność sprawia, że sztuka kościelna jest specyficznym rodza-

\footnotetext{
${ }^{68}$ A. SChILling, Überlegungen zur Gestaltung..., s. 16.

${ }^{69}$ K. B. Frank, Kernfragen kirchlicher..., s. 13, 37-38.

${ }^{70}$ J. Ballenstedt, Architektura. Historia ..., s. 619.
} 
jem sztuki użytkowej o charakterze wybitnie społecznym, wręcz wspólnototwórczym. Sakralny charakter obiektów kościelnych ma swe źródło w Uczcie eucharystycznej. Akcentowały to szczególnie gminy wczesnochrześcijańskie. Właśnie „chleb Pański” (coena Domini) ma ścisły związek z budowlą, co podkreśla św. Tomasz z Akwinu w swym traktacie o Eucharystii (S. Th. III 83, 3). Zauważmy, że w pismach Ojców Kościoła, szczególnie Klemensa Aleksandryjskiego czy Hipolita funkcjonuje nowa nazwa zgromadzenia liturgicznego: ecclesia, nie zaś „dom Boży”. Kamieniem węgielnym, ale zarazem pasterzem owego żywego Kościoła, jest sam Jezus Chrystus, który przez krzyż i śmierć nas odrodzil, który przez znak krzyża niesie zbawienie. Stąd krzyż odgrywa dominującą rolę zarówno w czasie liturgii, jak i - na ołtarzu ${ }^{71}$. Owa prosta i bezpośrednia funkcjonalność oznacza przede wszystkim przystosowalność pozytywną, liturgiczną całego budynku kościelnego, szczególnie jednak samego ołtarza i jego otoczenia.

\section{Charakter profetyczny}

Wszystkim, którzy mają wpływ na program, projekt i realizację obiektu sakralnego, należy przypominać utrwalone w tradycji stwierdzenie o milczącej katechezie i milczącym, a jakże wymownym kazaniu poprzez samą formę, atmosferę całej przestrzeni i wystrój wnętrza. To teolog i kaznodzieja może i powinien przekazać istotne przesłanie teologiczne, kerygmatyczne, biblijne, liturgiczne, pastoralne. Temu wszystkiemu ma z kolei twórca nadać odpowiednie kształty, proporcje, barwy i nastroje. To sztuka wsparta na fundamencie wiary, wraz z całym zapleczem różnych fachowców i doradców, posługując się właściwym sobie językiem twórczym „spełnia rolę p o śr e d n i c z e n i a między Bogiem a człowiekiem. Twórca sakralny, artysta bywa więc nazywany, w specyficznym tego słowa znaczeniu, kapłanem"72 oraz prorokiem. Znamienne w tym kontekście sa słowa pewnego niekatolika, iż każde wejście do kościoła katolickiego jest dla niego wsłuchiwaniem się w kazanie, również wówczas, gdy nie słyszy się kaznodziei ${ }^{73}$. Wymowna cisza przestrzeni kościelnej, także tej, która nie krzyczy obrazami ani nie dramatyzuje rzeźbami, staje się znakomitą płaszczyzną dialogu z sacrum, z samym Nieskończonym i Niewypowiedzianym. Obok owych kościołów bogatych i wybijających się krasomówstwem i wielosłowiem plastycznym, są też owe wyciszone, nasycone tajemnicą, a raczej Misterium i niemal ascetyczne w posługiwaniu się środkami artystycznymi.

${ }^{71}$ R. Grosche, Überlegungen zur Theologie..., s. 346.

${ }^{72}$ H. NADROwSKI, Wychowawcza funkcja sztuki religijnej i sakralnej, „,Ruch Biblijny i Liturgiczny" 4 (1973), s. 199. 
W wielkim organizmie Kościoła potrzebne jest i jedno, i drugie. Podobnie, jak przekaz Słowa Żywego może być i jest bardzo różny, podobnie jest z mową kościołów, ich murów i portali, polichromii i witraży. To wspaniałe, że Sobór Watykański II nie tylko nie zburzył owego, utrwalonego w tradycji, ewangelicznego i profetycznego przesłania budowli kościelnej (dawnej i nowej), ale doskonale to docenił i pogłębił.

Ważne jest nade wszystko to, na co Sobór zwrócił dobitnie uwagę: nic w przestrzeni kościelnej nie jest jakby niezależne, oderwane, niespójne. Wszystko ma współtworzyć nie tylko jedną, jednorodną przestrzeń, ale ma pełnić rolę służebną. Powiem więcej: najznakomitsze nawet dzieła historyczne czy współczesne mają tylko i o tyle sens w przestrzeni kościelnej, jeśli współtworzą główne i zasadnicze przeznaczenie kościoła. Obrazy, rzeźby, a tym bardziej ołtarze mają swoje znaczenie i sens nie jako dzieła „osobne" czy ozdobniki. One mają współorganizować przestrzeń, współtworzyć program ikonograficzny całości, w której wnętrzu nade wszystko ustawicznie uobecnia się Chrystus i urzeczywistnia żywy Kościół - właśnie poprzez sprawowaną tamże liturgię. Ostatecznie chodzi o coś więcej niż o usunięcie elementów rozpraszających czy konkurujących z ołtarzem ${ }^{74}$.

Budynek kościelny pełni również funkcję profetyczną. Musimy rozwinąć ten aspekt, stąd konieczność nawiązania do pewnych wysuniętych już uprzednio tez. Budowla kościelna najpierw poprzez swe kształty, strukturę i symbolikę, a również poprzez wnętrze - ma przemawiać do otoczenia ${ }^{75}$. Ma przemawiać do żywego Kościoła oraz liczyć się z jego problemami i potrzebami. Ta szczególna przestrzeń ma pomagać zrozumieć istotę oraz aktualne zadania Kościoła. Takie zrozumienie profetycznego posłannictwa całego Kościoła jest ważne nade wszystko dla architektów. Trzeba ciągle uświadamiać, że Kościół nie jest tylko czymś zewnętrznym czy pozornym, ale jest instytucją realną i symboliczną zarazem. Zauważmy, że dokumenty Soboru Watykańskiego II często wracają do charakterystycznego określenia Kościoła jako „sakramentu świata” (sacramentum mundi) ${ }^{76}$. Kościół jawi się jako skuteczne narzędzie wobec całego świata. Zwolennicy sekularyzacji i laicyzacji czy obojętności religijnej przyjmują jako założenie, że zarówno w życiu osobistym, jak i społecznym należy wszystko traktować „tak, jak gdyby Boga nie było [...], tak, jak gdyby wiara czy niewiara nie zmieniała niczego w rzeczywistości rzeczy. [...] Chrześcijaństwo, a raczej wyznawcy

${ }^{73}$ K. B. FrAnK, Kernfragen kirchlicher..., s. 6.

${ }^{74}$ H. NADROwsKI, Ottarz - jego charakter koncentrujący i funkcjonalny, „Ruch Biblijny i Liturgiczny" 6 (1972), s. 322n.

${ }^{75}$ E. LADNER, Ausdruck und Hinordnung im katholischen Kichenbau, „Werk” 12 (1961), s. 422.

${ }^{76}$ J. Groot, Świat i sakrament, „Concilium” 1-10 (1968), Poznań-Warszawa 1969, s. 18. 
nie przemieniają świata. [...] Wszystko się tak odbywa, jak gdyby wierzących tam nie było"77. Pod pozorem bardzo jednostronnie pojmowanego obiektywizmu oraz ,autonomii wartości świeckich”, próbuje się doprowadzić do faktycznej dechrystianizacji. Radykalny i tryumfalistyczny ateizm, jak również agresywna i pesymistyczna mentalność „religijnej próżni” próbują w nowoczesnej Europie obejść się bez Boga i Jego wpływu na duchowy i kulturowy charakter jednostek i społeczeństw. Zatraca się wartości wertykalne a sprowadza się wszystko jedynie do potrzeb horyzontalnych o charakterze konsumpcyjnym, hedonistycznym i bezrefleksyjnym. Wręcz „mówi się o postchrześcijańskiej Europie, o areligijnych tendencjach współczesnej mentalności, o końcu religijności kościelnej. [...] Można powiedzieć, że indyferentyzm religijny związany z tzw. nowoczesnością jest jakby dramatem społeczeństw najbardziej rozwiniętych gospodarczo, które wyeliminowały sacrum z życia codziennego i nie potrafią jeszcze stworzyć przestrzeni religijnej w łonie nowych modeli kulturowych"78. Natomiast posłannictwo, orędownictwo oraz „zbawczy wpływ Kościoła sięga daleko poza rzeczywiste granice jego głosu i poza miejsca sprawowania jego liturgii [...], sięga aż po krańce ziemi i czasów”. Tym niemniej to przede wszystkim „kult jest właściwym celem, dla którego istnieje Kościół i cały świat" 79 . Symbiozą zaś tego jest dokonująca się nieustannie „liturgia kosmiczna”.

\section{Funkcja świadczenia}

Mówi się także o funkcji świadectwa budynku kościelnego. Tak jak Pan Jezus był posłany na świat, by zbawiać oraz świadczyć poprzez ubóstwo i prześladowanie, podobnie Kościół powszechny, a także kościół jako budynek mają być obrazem takiego właśnie Chrystusa. Stąd wołanie o budowanie nowych kościołów w duchu ubóstwa. Nie oznacza to wcale, by miały być one nędzne, zaniedbane lub niechlujne. Pamiętajmy, że prawdziwe ubóstwo jest cnotą, a nie zaś brakiem czegoś. Jest świadomym wyborem wartości i godności poprzez prostotę, oszczędność i celowość. Dzięki temu mamy zyskać: wyrazistość i czytelność, oszczędność i rozwagę oraz prawdziwość zarówno materiałów, jak i przekazu. Proste kształty i tanie materiały powinny być domeną nowego budownictwa kościelnego - podkreślano już w latach powojennych ${ }^{80}$. Przepych i luksus niektórych kościołów w środo-

77 G. Girardi, Uwagi o obojętności religijnej, „Concilium” 1-10 (1966/1967), PoznańWarszawa 1969, s. 119, 121.

${ }^{78}$ J. MARIAŃSKI, Kościót a wspótczesne problemy społeczno-moralne. Kwestie wybrane, Lublin 1992, s. 230.

${ }^{79}$ J. Groot, Świat i sakrament..., s. 25.

${ }^{80}$ O. Moosbrugger, Die katholische Kirche..., s. 361. 
wiskach wielce zubożałych jest rodzajem obelgi i bluźnierstwa, a nawet - bałwochwalstwa. Funkcja dydaktyczna budowli kościelnej to także jej ustawiczna wymowa, a raczej ciągłe nieme kazanie ${ }^{81}$, dobre lub złe.

Jednocześnie, przestrzeń kościelna ma nie tyle podkreślać tak typowy dla renesansu, indywidualizm, ile charakter wspólnotowy, rodzinny. Skupiona bowiem podczas Świętej Liturgii wspólnota to przede wszystkim familia $D i^{82}$. Tutaj wszyscy obecni członkowie owej rodziny powinni czuć się bezpiecznie, blisko Boga i siebie. Tutaj każdy powinien pełnić właściwą sobie rolę. Gromadząca wiernych przestrzeń nie ma być tylko odwiedzana, oglądana czy podziwiana, ale angażująca do uczestnictwa oraz inspirująca do nowego myślenia i postępowania, czyli do świętości życia.

Na kształtowanie sztuki kościelnej, a szczególnie przestrzeni kościelnej, wpływ miały środowiska opiniotwórcze, ale także stan wiedzy estetycznej i pobożności danego czasu. Niebezpieczeństwo wciągania do sztuki sakralnej szarlatanów i propagatorów kiczów istniało tak kiedyś, jak i dziś. Zarazem obok tamtych trwają i wywierają wpływ na sobie współczesnych i na potomnych wspaniałe dzieła architektury i sztuki sakralnej, przestrzenie kościelne i strefy tchnące misteryjną zadumą. Także bardzo różnorodne i wciąż rozwijające się kierunki artystyczne i style kształtowania sacrum kościelnego naszych dni powinny zostawić trwały ślad w historii. Podkreślmy tu, że czymś więcej niż modą i kontrastem względem tradycjonalistycznych, jakże często dekoracyjnych i przeładowanych rozwiązań, stała się „architektura kubiczna". Owa przestrzennośćc ${ }^{83}$ stała się wymogiem czasów, ale i zarazem funkcjonalną koniecznością. Usunięto elementy nieistotne, niepodporządkowane, naleciałości epok minionych, cały balast, czyli to wszystko, co zakłóca spójność i związek z liturgią.

\section{Wymiar eschatyczny}

Jak słusznie zauważa R. Grosche, kościół jest nie tylko miejscem gromadzącym chrześcijan, ale też miejscem, w którym ciągle uświadamiane jest p r z e j ś c i e społeczności wiernych do królestwa Bożego ${ }^{84}$. Dotykamy tu znamienia paschalnego i eschatycznego budowli kościelnej.

Pozostaje jeszcze jedna, ontycznie i teologicznie podstawowa, interpretacja przestrzeni kościelnej-w tym i samego budynku kościelnego. Chodzi tu

${ }^{81}$ E. MANFredini, Riflessi della reforma liturgica sull'architettura della chiesa, „Fede e Arte" 2 (1965), s. 246.

${ }^{82}$ H. Muck, Sakralbau heute..., s. 27.

${ }^{83}$ Tamże, s. 36-38.

${ }^{84}$ S. Stehman, Points de vue sur..., s. 305; A.-M. Roguet, Construire et aménager ..., s. 26 : „Un peuple en marche”. 
o wymowę symboliczną i mistyczną, opartą na podstawach b i b l i j n y c h . Otóż każdy kościół jest nie tylko dziełem Bożym, jak cały świat, ale także domem, w którym w szczególny sposób mieszka żywy i prawdziwy Bóg. W tym kontekście słowa: „Bóg, który stworzył świat i wszystko na nim, On, który jest Panem nieba i ziemi, nie mieszka w świątyniach zbudowanych ręką ludzką" (Dz 17, 24) wydają się stać w sprzeczności z utrwaloną w tradycji i nazewnictwie kościoła jako Domu Bożego. Chodzi tu o różne stany obecności Chrystusa: historyczną, mistyczną, eucharystyczną czy duchową - pośród zgromadzenia liturgicznego. Kościół jest miejscem, w którym nie tylko mieszka Bóg, ale, także my - ludzie, a szczególnie my - chrześcijanie „w Nim żyjemy i poruszamy się i jesteśmy" (Dz 17, 28). Jest to więc dom żywego ludu Bożego i dom

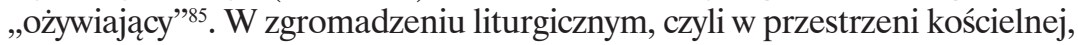
uobecnia się ustawiczne oczekiwanie na przyjście Pana, co nabiera wymiaru eschatycznego. Tu także urzeczywistnia się Kościół egzystencjalny (hic et nunc). Określenia takie jak: „dom Boży” (1 Tm 3, 15), „świątynia Boża” (2 Kor 6, 16), „mieszkanie Boga” (Ef 2, 22), mają nie tylko wydźwięk poetycki czy są przenośnią literacką, ale odzwierciedlają zarazem najgłębszą rzeczywistość przestrzeni kościelnej w interpretacji teologicznej i biblijnej. W najpełniejszym znaczeniu owa szczególna obecność Boga urzeczywistnia się poprzez nowe człowieczeństwo ludu Bożego. To sam lud Boży jest „domem Bożym”. W tym miejscu dotykamy owej głębszej, nadprzyrodzonej obecności Boga Ojca, Jezusa Chrystusa i Ducha Świętego w wierzących. Dobitnie tę myśl wyraża znany teolog Hans Urs von Balthasar: „im przejrzyściej chrześcijaństwo jako całość” ukazuje, pośród doczesności i teraźniejszości, autentyczną wiarę i jej konsekwencje, „w tym większym stopniu uczyni ono znów świat teofanicznym”" Możemy powiedzieć, że chrześcijanie są, a raczej powinni być żywą świątynią Bożą pośród tego świata. Jakżeż oczywiste stają się słowa św. Pawła: „Czyż nie wiecie, żeście świątynią Boga, i że Duch Boży mieszka w was?" (1 Kor 3, 16). „Świątynia Boga jest święta, a wy nią jesteście” (w. 17). „Czyż nie wiecie, że ciało wasze jest przybytkiem Ducha Świętego, który w was jest, a którego macie od Boga" (1 Kor 6, 19). Znamienne są słowa św. Piotra powiedziane w kontekście powszechnego kapłaństwa: „Wy niby żywe kamienie jesteście budowani jako duchowa świątynia, by stanowić święte kapłaństwo, dla składania duchowych ofiar, przyjemnych Bogu przez Jezusa Chrystusa" (1 P 2,5). Święty Paweł akcentuje aspekt permanentnego wzrastania i budowania we wspólnocie postawionej na fundamencie Apostołów i proroków, gdzie kamieniem węgielnym jest sam Chrystus Jezus. „W Nim zespalana cała bu-

${ }^{85}$ T. Filthaut, Kirchenbau und Liturgiereform, Mainz 1965, s. 6.

${ }^{86}$ H. U. Balthasar, Spotkanie z Bogiem w świecie dzisiejszym, „Concilium” 1-10 (1965/ 1966), Poznań-Warszawa 1968, s. 428. 
dowla rośnie na świętą w Panu świątynię, w Nim i wy także wznosicie się we wspólnym budowaniu, by stanowić mieszkanie Boga przez Ducha” (Ef 2, 2022). W najgłębszym teologicznym uzasadnieniu to najpierw i przede wszystkim sama łaska sprawia, że wierzący staje się „domem Bożym, świątynią, w której Bóg mieszka, przybytkiem Najwyższego. [...] Ona przywraca duszy naszej, zgodne z wolą Bożą, pierwotne jej przeznaczenie; katedrą być mamy, wielkim ołtarzem, gdzie Bóg sam mieszka, by w nas działać. Łaska czyni ołtarz serc naszych «świętym Bogu»" (por. Wj 28, 36). Tak więc, każdy trwający w stanie łaski, staje się świętszy od jakiegokolwiek kościoła czy ołtarza, które choć do Boga się odnoszą i Jemu są poświęcone, to pozostają jednak nie dziełem samego Boga, ale dziełem rąk ludzkich ${ }^{87}$. Romano Guardini dobitnie mówi o potrzebie pokory tych, którzy uczestniczą w świętej liturgii, a szczególnie, gdy jej przewodniczą ${ }^{88}$. Czyż w stopniu szczególnym właśnie pokorą nie powinien odznaczać się twórca sakralny, który głębi swego przekazu powinien szukać w Bogu, a efekty swej pracy odnosić do wspólnoty wiernych, do potrzeb konkretnych parafian?

Przystęp do tej świętej Rzeczywistości wpisanej w przestrzeń i mury kościoła ma każdy człowiek dobrej woli. „Związek bowiem poszczególnego chrześcijanina z Kościołem nie jest nigdy” zewnętrzny i formalny; „każdy chrześcijanin ma bezpośredni przystęp do serca misterium, i znaczenie jego nie zależy od zajmowanej przezeń społecznej czy kościelnej pozycji, lecz od jego osobistego uczestnictwa w życiu ducha, który ożywia Kościół”89.

\section{Sugestie}

Oddzielne studium trzeba by poświęcić poszczególnym strefom zewnętrznym, a szczególnie wewnętrznym całego obiektu sakralnego. Cenne też zapewne okazałoby się oddzielne opracowanie, które przeanalizuje drogi do ukształtowania liturgicznych wymogów Vaticanum II odnośnie do przestrzeni kościelnej. Równie cenna, choć momentami dramatyczna może okazać się konfrontacja założeń Drugiego Soboru Watykańskiego dotycząca budowli kościelnej, zabytkowej i stawianej współcześnie, z rzeczywistością w różnych krajach, w tym także w Polsce. Te zadania trzeba jednak wykonać. Także, by uchronić przed dalszymi pomyłkami czy błędnym odczytaniem ducha minionego Soboru. Kto wie, czy właśnie „Ruch Biblijny i Liturgiczny" nie byłby najlepszym forum po temu?

\section{Poznań}

KS. HENRYK NADROWSKI MIC

\footnotetext{
${ }^{87}$ P. Lippert, Łaski Boże, Kraków 1934, s. 11n.

${ }^{88}$ R. Guardini, O duchu liturgii, Kraków 1996, s. 73-78.

${ }^{89}$ C. Dawson, Formowanie się chrześcijaństwa ..., s. 266.
} 